Relations industrielles

Industrial Relations

\title{
Pour une économie des besoins, Economie et Humanisme, Le diagnostic, No 84, mars-avril 1954.
}

\section{Gérard Dion}

Volume 9, numéro 3, juin 1954

URI : https://id.erudit.org/iderudit/1022883ar

DOI : https://doi.org/10.7202/1022883ar

Aller au sommaire du numéro

Éditeur(s)

Département des relations industrielles de l’Université Laval

ISSN

0034-379X (imprimé)

1703-8138 (numérique)

Découvrir la revue

Citer ce compte rendu

Dion, G. (1954). Compte rendu de [Pour une économie des besoins, Economie et Humanisme, Le diagnostic, No 84, mars-avril 1954.] Relations industrielles / Industrial Relations, 9(3), 302-302. https://doi.org/10.7202/1022883ar

Tous droits réservés @ C Département des relations industrielles de l’Université Laval, 1954
Ce document est protégé par la loi sur le droit d'auteur. L’utilisation des services d'Érudit (y compris la reproduction) est assujettie à sa politique d'utilisation que vous pouvez consulter en ligne.

https://apropos.erudit.org/fr/usagers/politique-dutilisation/ 
tions are and how effective they can be in creating confidence among workers themselves and among the various degrees of supervision; the result of such an effort is coordinated teamwork vital to the company's success.

Various methods are used to "secure a flow of information up and down the organization". An example of good communication bringing good results of exchange of ideas and feelings that took place is given in the paper; it is mentioned that "the plant had gone to considerable effort and expense to get this exchange". Something should be remarked in that fact and it is that this progress was made over a number of years and not instantly. More and more facts about the company were revealed frankly to every people in the plant and in that way they were receiving a more interesting economic education than real economic courses would have given them. They are concerned in how their company's economics affect their own security.

Such educational sessions were taking place under group discussion, conferences and weekly staff meetings. Furthermore, the general superintendent held meetings with the union representative. In such a way of proceeding, every group and every person could share every information; the middle management and supervisors felt secure in being able to and having to pass information along. It also should be noted that the foreman has a job to do in his own group in bringing information to the group and getting information from the group to management.

The most important aspect of making information well known to every one is that "it' constitutes recognition of the importance of the individual and the fact that he does play a part in the scheme of business". Such an attitude in a Company brings confidence, cooperation and success.

\section{Fabienne Tousignant}

Pour une économie des besoins, Economie et Humanisme, Le diagnostic, No 84, mars-avril 1954.

Ce cahier contient quelaues-unes d'une série d'études qui ont été présentées à la session sur le besoin tenue en
1953. On y avait abordé deux points importants: le besoin en général et les divers besoins, la réponse aux besoins. Notons certains travaux très remarquables: J. Y. Calvez, Le besoin devant la pensée écoomique et philosophique; $\mathbf{M}$. Marczewski, Les régions économiques et notamment le régime soviétique, face aux besoins; Parizeau, Besoins globaux et croissance orientée des pays sousdéveloppés et G. C. Sebregondi, Le développement harmonisé: notes pour une théorie. Ce cahier présenté selon les préoccupations des recherches d'Economie et Humanisme est une excellente contribution à l'étude de la théorie économique.

Gérard Dion

HUDSON, Ruth Alice and ROSEN HJalmar - Union Political Action: The Member Speaks - Industrial and Labor Relations Review, Volume 7: Number 3, April 1954, pp. 404-419. Issued quarterly by New York State School of Industrial and Labor Relations at Cornell University, Ithaca, New York, $\$ 5.00$ a year $-\$ 1.50$ a copy.

Les auteurs, l'une assistante du professeur de sociologie et l'autre assistant professeur de psychologie à l'Université d'Illinois ont complété, au printemps de 1952, une enquête effectuée auprès des membres d'une union régionale groupant 21 locaux pour un total de 25,000 membres dans un centre commercial et industriel des Etats-Unis. L'article en question veut être un rapport sur ce qu'un groupe de membres pensent du rôle des unions dans le domaine politique. Les auteurs expliquent leurs méthodes, leurs constations et leurs conclusions par graphiques et tableaux. C'est une étude scientifique et techniaue. Ils ont posé, à un échantillonage de 4.281 «rank-and-file members 》 et ̀े 969 «stewards 》 ou officiers de ces locaux, cinq questions: Les unions devraient-elles prendre une part active à la politione? Devraient-elles supporter tes candidats favorables aux travailleurs? Devrait-on discuter de questions politiques dans les assemblées? Les unions devraient-elles indiquer aux membres des dons pour des campagnes électorales? L'étude comporte une ana- 